\title{
Nikolay Ivanovich Pirogov as an innovator in anatomy, surgery, and anaesthesiology. Part II
}

\author{
I. F. Hendriks ${ }^{1}$, D. A. Zhuravlev², J. G. Bovill'1, F. Boer ${ }^{1}$, P. C. W. Hogendoorn ${ }^{1}$, \\ M. C. DeRuiter ${ }^{1}$, I. V. Gaivoronskii ${ }^{3}$ \\ ${ }^{1}$ Leiden University Medical Center, Leiden, Netherlands \\ 2Military Medical Museum, St. Petersburg, Russian Federation \\ 3S.M. Kirov Military Medical Academy, St. Petersburg, Russian Federation
}

This article is the second of two articles on Nikolay Ivanovich Pirogov. In the first article "Highlights of the professional activities of Nikolay Ivanovich Pirogov before and after his professoriate in Saint Petersburg (1841-1860)." we discussed his early training and his professional development at the Dorpat University and abroad till his appointment in Saint Petersburg 1841. Also is discussed how during and after his professoriate in Saint Petersburg he developed management of mass war casualties. In this second article we highlight his professional career as an anatomist, surgeon and anaesthesiologist. The authors want to emphasize that these two articles are an extract from previously published extensive articles related to Nikolay Ivanovich Pirogov. You can find these articles in the reference list under the name of the first author [12-17].

Key words: the Netherlands, Russia - (pre 1917), Nikolay Pirogov, history, medicine.

\begin{abstract}
Николай Иванович Пирогов как инноватор в анатомии, хирургии и анестезиологии. Часть II

(С) И. Ф. Хендрикс ${ }^{*}$, Д. А. Журавлев ${ }^{2}$, Дж. Г. Бовилл ${ }^{1}$, Ф. Бур ${ }^{1}$, П. С. У. Хогендурн ${ }^{1}$,

М. К. ДеРуйтер ${ }^{1}$, И. В. Гайворонский 3,2020

${ }^{1}$ Медицинский центр Лейденского университета, Лейден, Нидерланды

${ }^{2}$ Военно-медицинский музей, Санкт-Петербург, Россия

зФГБВОУ ВО «Военно-медицинская академия им. С.М. Кирова» Минобороны России, Санкт-Петербург, Россия

Эта статья является второй из двух статей о Николае Ивановиче Пирогове. В первой статье «Основные вехи профессиональной деятельности Николая Ивановича Пирогова в Санкт-Петербурге (1841-1860)» мы обсуждали его обучение и профессиональное развитие в Дерптском университете и за границей до его отъезда в Санкт-Петербург в 1841 году. Также в статье обсуждается тот факт, что и в период своей профессиональной деятельности в Санкт-Петербурге, и в последующие годы Н.И. Пирогов занимался разработкой способов лечения пострадавших в военных действиях. Во второй статье мы освещаем его профессиональную карьеру как анатома, хирурга и анестезиолога. Авторы хотят подчеркнуть, что эти две статьи являются отрывком из ранее опубликованных обширных статей, касающихся Николая Ивановича Пирогова. Эти публикации можно найти в списке литературы под именем первого автора [12-17].
\end{abstract}

Ключевъе слова: Нидерланды, Россия (до 1917 г.), Николай Пирогов, история, медицина.

*Corresponding author:

Inge F. Hendriks, MA,

Department of the Executive Board, Post zone H-01-46,

Leiden University Medical Centre, PO Box 9600, 2300 RC

Leiden, The Netherlands

E-mail: i.f.hendriks@lumc.nl

\section{Professor of applied anatomy and hospital surgery in Saint Petersburg}

In 1838 the Medical-Surgical Academy in Saint Petersburg was transferred to the Ministry of Defence. This created a new chair of surgery, which was offered to Pirogov. Before he accepted the appointment he negotiated his terms [45, 49]. He wanted to combine the didactic teaching of surgery with practical, hands-on experience at the bedside of the sick, and exposure of young students to scientific principles. In this respect Pirogov's approach to medical education was very much in keeping with the teaching of the Dutch physician, Herman Boerhaave, who had re- introduced bedside teaching in Leiden in the Netherlands in the early $18^{\text {th }}$ century [2] Pirogov considered Boerhaave, the English physician Thomas Sydenham, and the French barbersurgeon, Ambroise Paré, as medical geniuses. He did not consider himself equal to these men "...We are not Boerhaave, nor Sydenham or Paré...” [23, 27]. He suggested the establishment of a new Department of Hospital Surgery in the Academy [23]. It took some time but in March 1841 all Pirogov's proposals were accepted and he was appointed as Professor of Applied Anatomy and Hospital Surgery at the Medical-Surgical Academy and chief surgeon of the Second Military Landforce Hospital (with 1000 beds) and would keep that position till 1860 [6, 45, 47, 49]. He became a member of the Committee under the Ministry of Public Education for the transformation of the medical curriculum including for the first time the teaching of topographical 
and applied anatomy at universities; was appointed one of the four members of the Medical Council of the Ministry of the Internal Affairs; secretary for the Academy of Science and technical director of the St. Petersburg medical tool factory [40]. He also worked as a consultantsurgeon in three other hospitals in the city and ran a busy private practice. His aim was: “...To assist in raising the medical skills in Russia to a level equal to that of the advanced countries of Europe..."[49, 54].

\section{A plan for teaching microscope at the Imperial Medico-Surgical Academy}

In 1825, while Pirogov was still studying in Berlin, practical and theoretical courses in microscopy were introduced in the main medical institutes of this city [27]. Since then, Pirogov had attached great educational value to practical studies in microscopic anatomy and histology. In 1841 Pirogov, with his new colleague Karl Ernst von Baer, a naturalist and biologist, presented a plan to the Imperial Medico-Surgical Academy for the teaching of microscopy and histology to acquaint students with the latest developments in medical science, which was accepted. The anatomy department was the proud owner of the best available achromatic microscope at that time, manufactured by Simon Plössel (1794-1868) and a selection of microscopic slides, a gift from Vienna University. In a book published in 1839 [27] Pirogov described the importance of the microscope for investigating the influence of altered blood corpuscles on the capillary system. Pirogov even promoted the creation of a histology chair, but this only came to fruition in 1857 .

In the first of his series of monographs on clinical surgery, published in 1854, Pirogov argued that microscopic examination is indispensable in distinguishing the various forms of lip carcinoma from trivial injuries like a burn from a cigarette or a neglected tear of the lip. He wrote that "...The microscope is much more indispensable than the stethoscope, which in most cases can be replaced by a practiced ear..."[40]. He recommended the Brunner pocket microscope to his readers as it magnifies up to $\times 400$ and had a field of view almost as wide as the portable field microscope which Pirogov always carried with him.

\section{The Anatomical Institute}

During his first years in Saint Petersburg Pirogov started to work on a textbook on Applied Anatomy [29]. Visiting the local meat market Pirogov noticed that when butchers cut frozen pig's carcasses the positions of the internal organs were clearly seen [50]. He realised he could use a similar method and taking advantage of the cold Russian winters he froze cadavers "to the density of the thickest wood" and cut them into thin plates. This allowed him to describe the topographical anatomy of the human body in a detail never before attempted. It took him eight years of work before he could publish his atlas of topographical anatomy [43].

In 1844 Pirogov wanted to add an Anatomical Institute to the Academy [45]. It took two years before permission was granted. In 1846 Pirogov, together with Carl Johann von Seidlitz and Karl Baer, formed the Institute for Applied Anatomy, with Pirogov as the director. Unfortunately, at the end of January 1846 before Pirogov could take up his post as director his wife died after the birth of their second son [45]. To help overcome his grief the Academy gave him a grant to visit anatomical departments in Europe. During his travels he met Wencheslav Leopoldovich (Wenzel) Gruber, a former student of the Viennese anatomist Josef Hyrtl (1810-1894) [10, 45]. In 1847 Pirogov invited Gruber to become his first prosector at the Imperial Medico-Surgical Academy. The combined skill of Pirogov and Gruber worked out as a marriage made in heaven. After Pirogov's resignation in 1855 Gruber took over the leadership of the Anatomical Institute and in 1858 he became a full professor.

In the anatomical institute Pirogov instructed medical students and doctors in pathological and surgical anatomy, surgical procedures on cadavers and combining practical work. Teaching was done in rooms specially designed for microscopy studies and experimental work on animals. The institute also functioned as a postgraduate education center for those who wanted to improve their knowledge both in the field of surgery and of surgical and pathological anatomy. Further the institute had a function to train future teachers of anatomy, not only for the Academy but also for other educational and medical institutions in Russia. During his 15 years at the Academy Pirogov carried out and/or supervised about 12,000 autopsies, which were done on all patients who died in the hospital clinics of the Academy. The introduction of the new diagnostics methods in the clinic and the practical microscopic courses, histology, anatomy and symptomatology were important new steps in medical teaching in the 1840 s in Russia. Other Russian medical institutes later followed the path taken by the Imperial Medico-Surgical Academy [18].

\section{The implementation of anaesthesia in surgery}

When Nikolay Pirogov learned about Morton's demonstration of ether anaesthesia and the interest of the Russian government in this new development he began experimenting with ether in January 1847 [4, 54]. Pirogov initially hesitated to use ether, because he was worried about the safety of the technique and the effects during the recovery from anaesthesia. He investigated the clinical course of ether anaesthesia on himself and his assistants before using it on his patients $[1,31,32]$. He carried out his first two operations under ether anaesthesia on 14 February 1847 in 


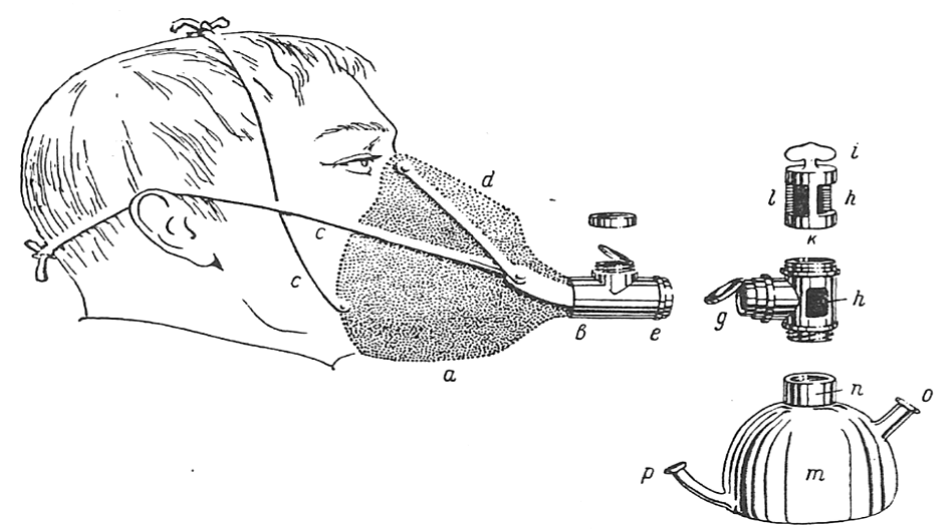

Fig. 1. Device for inhalation of ether vapour developed by N.I. Pirogov [32]. Ether vapour from flask $(m)$ enters the inhalation valve (h) where it mixes with air inhaled through openings in the valve. The amount of mixing, and thus the inspired concentration of ether, was controlled by the tap (i) on the upper half of the inhalation valve. The ether/air mixture was inhaled by the patient via the tight fitting face mask connected to the inhalation valve by a length of tubing containing an exhalation valve. The face mask designed by Pirogov to fit snugly around the mouth and nose of the patient was an entirely new innovation at that time. In the public domain. the $2^{\text {nd }}$ Military Land Force Hospital in St. Petersburg, using a simple green bottle with a rubber tube inserted into the patient's nose for inhalation of ether vapor. He was convinced that ether anaesthesia was '....a remedy, that in one sense can transform the whole of surgery...' [31, 32]. He published his first monograph on the subject on 17 May 1847 [30, 31, 53]. Pirogov submitted papers to the Académie des Sciences in Paris describing his experiences [30, 52]. He wrote a book in which he described his experience of administering ether to 40 animals and 50 patients [31]. The purpose of the manual was to provide physicians with information about the effects of ether anaesthesia, details about the construction, and use of the inhalation device for its administration [9, 52] (Fig. 1). Although he was convinced that the discovery of ether anaesthesia was one of the greatest achievements of science, he was also very much aware of its limitations and dangers [31, 32].

The Tsar was aware of Pirogov's research and results and insisted that ether should be used in surgical operations during the Caucasian campaign in 1847 , not only for humanitarian but also for tactical reasons [32]. En route, Pirogov visited several towns and cities where he introduced ether anaesthesia to the local physicians [53]. He used it widely in the summer of 1847 during the Caucasian War [12]. He also carried out experiments with rectal administration of ether on animals and later also in patients. Compared to the inhalation route, rectal anaesthesia developed much quicker (within 2-3 minutes) and the patients were more deeply anaesthetised, with better muscle relaxation. Rectal anaesthesia also lasted longer (about 15-20 minutes) than inhalation anaesthesia, more major operations could be performed. However, he quadually became much less enthusiastic, and rectal ether never achieved widespread popularity. During the period February 1847 - February 1848 Pirogov gathered data on operations performed under anaesthesia both on the battlefield and in military and civilian hospitals. Of the 580 operations for which sufficient data were available, he described and summarised in his book Medical Report from a Trip to the Caucasus his views about anaesthesia and its importance for surgery [31, 32].

After his return from the Caucasian War, Pirogov administered his first anesthesia with chloroform on 21 December 1847 in Moscow; the subject was a large dog $[48,60]$. Chloroform had obvious advantages over ether for use in the field. The quantity needed for effective anaesthesia was small; unlike ether it was not inflammable; and it did not require complicated equipment, since anaesthesia could easily be induced using a simple rag-and-bottle technique.

Based on his observations and analyses he was convinced that mortality was not increased by the administration of ether or chloroform [32]. This was contrary to the observations of French and British doctors, (influenced partly by the famous case of Hannah Greener) that the administration of chloroform could lead to sudden cardiac death, or as Glover suggested, of intense lung congestion from the toxic action of the anaesthetic [8]. Pirogov surmised that the deaths described by the French and British doctors were the result of too rapid and excessive administration of chloroform [32]. None of the deaths among the patients to whom Pirogov gave chloroform during the Crimean conflict were related to anaesthesia, nor were there any reports of chloroform-related deaths in the Russian field hospitals. The Russian medical service performed every operation under chloroform, rather than using ether. Over 9 months, he personally performed 5000 amputation, that's 30 a day.

From personal experience, Pirogov warned against the administration of anaesthesia by untrained assistants. Based on his military medical experience at Salta during the Caucasian conflict, he became convinced of the effectiveness of physicians dedicated to administering anaesthesia, assisted by trained helpers [3, 32]. His main argument was that operations under anaesthesia were often more complicated, and tended to last much longer, than those without anaesthesia, so that the surgeon could not concentrate on the surgery and at the same time provide adequate care for the anaesthetised patient. During the Crimean War his experience of the use of 
anaesthesia had increased immeasurably. The widespread use of anaesthesia by Pirogov during this war had a most significant influence on the subsequent advancement of anaesthesia for the general population in Russia, in which development he played a crucial and central role [25].

\section{The cholera epidemic of 1847}

In 1847 when the Caucasian War had ended and traveling home Pirogov was confronted with a raging epidemic of Asian cholera [32]. Pirogov observed the disease at the various stages of the epidemic and was able to study the progress, symptoms and treatment of the disease. He developed an atlas of the pathological anatomy of the disease [33], together with a textbook on the subject [35], based on the approximately 500 autopsies that he had carried out or supervised. His objective was to provide clear pictures that would help his colleagues better understand the disease. The drawings for both were done by Mr. Terebeniev and Mr. Meyer and with the significant financial support of the Imperial MedicoSurgical Academy in Saint Petersburg. Most of the atlas depicted pathological changes in the intestinal mucosa. Pirogov believed that the damage caused by cholera was largely to the intestinal canal. The atlas of the Asian cholera was extensively reviewed by Virchow in 1852 [58]. He praised the quality of the atlas, although he expressed some reservations about what he thought was a lack of detail in some areas. However, Virchow [35] did not have access to Pirogov's textbook that extensively described the plates and the systematic analysis of Asian cholera.

\section{Teaching Applied Anatomy}

Between 1843 and 1848 Pirogov worked on a book that reproduced natural drawings of the human body intending to teach physicians about applied anatomy [28]. The drawings in the book were layered so that readers could obtain a threedimensional image of the structures. The fascial and synovial sheaths and inter-fascial spaces in the lower limbs were illustrated in detail. He published the book on the upper and lower limbs inclusive of the foot and the hand in several issues. In an accompanying textbook, printed in both Russian and German, a detailed one-and-a-halfpage explanation was given of each illustration. His original intention was to publish 25 issues but was only able to manage 12 issues because the publisher was declared bankrupt.

In 1850 Nikolay Pirogov produced an anatomical atlas with illustrations in colour, which was published by the Military Medical Journal and still exists today [34]. The Journal editors decided to reproduce Pirogov's anatomical drawings using lithography to preserve the elegance and accuracy of the originals. However, because of the considerable costs involved in producing each individual lithograph it was published in only a very limited edition. This allowed the price to be kept lower and thus more affordable for those involved in anatomy, especially for the forensic specialist, as both Pirogov and the editors considered it a textbook for those carrying out autopsies. It was difficult to reproduce the lithographs in the atlas because of the small dimensions requested, not only for the journal itself but also for the five engravers involved.

\section{Anatomy as a value to forensic pathology and disarticulation and resection}

Nikolay Pirogov was interested not only in anatomy and its application to surgery but also in its value to forensic pathology [32, 45]. During the Caucasian conflict in the summer [12].

Pirogov dealt with over 2,000 gunshot wounds of which only 15 serious injuries were caused by large projectiles such as shells. In most cases the results were either amputation or the death of the victim. Pirogov was determined to find a better surgical approach by observing and analysing. The availability of anaesthesia allowed Pirogov to carry out a much greater examination of the soldiers with large bone fractures caused by gunshots $[13,32]$.

The differences of the injuries he observed were the result of gunfire from Russian, Lesgian or Asian rifles. They differed in sizes, weights and velocity of the bullets. The Russian bullets were heavier ( $56.8 \mathrm{~g}$ ) with a low velocity which caused considerably larger exit wounds than entry wounds and with more extensive tissue damage. In contrast to riffles used by the rebels, Lesgian and Asian troops, who used small and light bullets $(12 \mathrm{~g})$. These bullets travelled at high speeds, caused small similar entry and exit wounds of the same size and were sometimes barely perceptible with considerably less tissue damage.

After the Caucasian conflict Pirogov was able to put the experience he had gained to good use. He experimented and analysed the relationship between the velocity of the bullets of different firearms and bullets, and the characteristics of the entry and exit wounds on animal carcasses, guided by observations and his knowledge of anatomy. (Pirogov, 1849a) He considered a gunshot wound the headache of a surgeon, because “... an injury produced by a bullet must be seen as the path of a fistula, which needs to be opened to give passage to the pus that constantly accumulates and let the law of hydraulics do its work..." [32].

Pirogov introduced the disarticulation of joints and resection of bones as a means of saving limbs, in particular the upper limbs, instead of amputations, then the only method of surgical treatment for gunshot fractures. Pirogov believed that in selected cases these procedures could save a limb with fractured bones, provided that major blood vessels or nerves were not damaged. In these cases, resection of the shattered bone should be immediately undertaken and the limb 


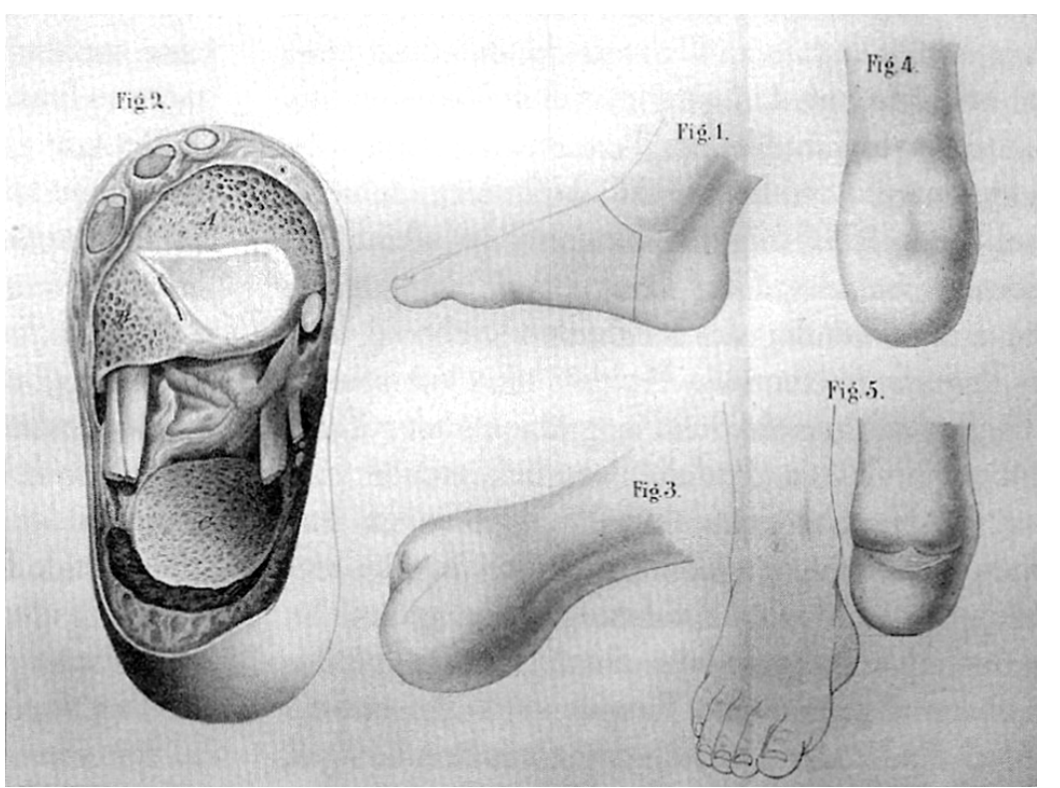

Fig. 2. Drawings showing the stages in Pirogov's foot amputation [40]. Figure 1 in the drawing shows the cut surfaces from the side, Figure 2 the surface after disarticulation of the foot, figures 3 \& 4 views of the stump and figure 5 the stump as viewed from the front. The difference in length between the two legs is only 1-1.5 inches $(5.54-3.8 \mathrm{~cm})$. In the public domain. should be immobilised. However amputation was sometimes unavoidable [32].

In 1862 Pirogov was asked for a consultation by colleague surgeons, who treated the Italian freedom fighter Giuseppe Garibaldi. He had been shot in his foot during the Italian unification conflict [44]. None of the surgeons from Italy, Britain or France could decide where the bullet was located and thus the best method of treatment. Pirogov was able to determine that the bullet was located at the lower part of the tibia close to the lateral malleolus. He advised a conservative treatment, i.e. no immediate surgical intervention to remove the bullet. Pirogov's advice was followed and within six weeks the bullet had spontaneously migrated to just under the skin and was easily removed. The patient made a full recovery and in a letter Garibaldi warmly thanked Pirogov [11].

\section{The "Pirogov amputation"}

During his trip through Europe in 1846, Pirogov observed two patients who had undergone a foot amputation following the Syme method, and who were able to walk without discomfort. He was so impressed that he determined to use this operation on his return to Russia. As always, Pirogov did not immediately use the method on his patients. Because experiments on cadavers revealed several problems with the Syme method he devised his own approach to amputation of the foot, now known as the Pirogov amputation, and the world's first osteoplastic surgery [40]. Pirogov's method differs from Syme's in that the posterior part of the calcaneus with the insertion of the Achilles tendon remains attached to the posterior flap. The advantage was that there is only a minor shortening of the limb and the patient could walk without needing a prosthesis due to the maintenance of the calcaneal fragment fused to the tibia. This results in a high loading capacity stump not dissimilar to a natural heel (Fig. 2). Pirogov described his method in the first volume of his textbooks on Clinical Surgery, a collection of monographs in three volumes [40]. He also published a detailed description of his technique in the medical journal Voenno-Meditsinskiy Zhurnal [42].

Pirogov's surgical method was so innovative that it initially met with harsh and often unfounded criticism by some contemporary colleagues. About these criticisms Pirogov wrote "...Although Stromeyer doubts the success of my foot osteotomy plastic surgery, Fergusson makes me an apostate and Syme rejects it as an antisurgical procedure, so it deserves but special consideration on the part of the war surgeons..." [40]. However, in Pirogov's support Theodor Billroth confirmed that he had applied Pirogov's method to the satisfaction of his patients: "...(They) go admirably on their stumps..." [50]. Pirogov's method is still used today although modifications have been made to improve outcome and reduce risks of complications [19, 24, 56].

\section{Forerunner of the plaster of Paris cast}

The second volume of Pirogov's monographs on clinical surgery dealt with fractures and dressings. As discussed earlier, the choice of treatment for fractures caused by bullets was often immediate amputation or immobilization in the hope that the fracture would heal. The accepted method of immobilization was developed by the Belgian army surgeon Louis Seutin (17931865) $[7,51]$. Pirogov was dissatisfied with the starched cast based on the method of Seutin [41]. Antonius Mathijssen could also not satisfy him with two layers of bandages pre-impregnated with dry plaster powder stored in sealed containers. This method was also time-consuming and the dressings of the dry plaster crumbled easily.

Seutin's method used cardboard splints and bandages soaked in starch dissolved in hot 
water and applied wet. Because cardboard was not readily available on the battlefield Pirogov used straw mixed with starch. A major disadvantage of these dressings was that hot water was seldom available on a battlefield, and they took 2 to 3 days to dry. Although not quite satisfied with the "fixed bandage", their use together with anaesthesia created for Pirogov new possibilities for the development of surgery [32, 45, 46]. He continued to develop the starched cast and its implementation because he was no longer willing to amputate when this was not absolutely necessary.

Pirogov observed how sculptors used strips of linen soaked in liquid plaster of Paris for making models. Based on this observation, in $1851 / 1852$ he developed his own method for immobilization of fractures, using canvas soaked in a plaster of Paris mixture immediately before application to the limbs, which were protected either by stockings or cotton pads. The preparation of plaster cast required no boiling water, and it hardened immediately and was so hard that splints were not needed, even when large drainage windows were created. Pirogov, as a good manager, was well aware of the treatment costs involved and stated "...The simpler, faster and cheaper the creation of such a bandage is as a replacement for the manual action, so suitable and advantageous it is for the hospital practice. Even old rags would not be lost, they could be washed clean..." [41].

\section{Three-dimensional Topographic Anatomy of the human body}

When visiting the local meat market during the very cold winter of 1846 Pirogov noticed in a butcher shop that the frozen carcasses of pigs on display and which had been sliced open gave a clear view of the positions of the animal's internal organs [57]. He realized that he could also take advantage of the cold Russian winters to freeze cadavers "to the density of the thickest wood" and then cut them into thin slices. This would allow him to describe the topographical anatomy of the human body in a detail never before attempted. It would allow him to overcome one of the problems associated with the standard approach to determining the exact location of organs within the living body. During an autopsy the incisions made in the corpse, and the opening of the body cavities, can cause the position of the internal organs to change. This is especially the case when the abdomen or the thoracic cavity is opened; the intestines fall away from the abdominal wall and in the thorax the lungs collapse.

Pirogov and his team studied cadavers that had been frozen to at least minus 15 degrees Celsius [36]. As director of the Medical Instruments Factory in St. Petersburg he was able to use its facilities to make a special mechanical saw, constructed along the lines of those used by furniture makers, allowing him to make cuts of $1 ; 1 / 2 ;$ or $1 / 4$ centimeter thickness. Pirogov was of course aware that thin cuts in only one direction would not allow the exact location of organs to be determined. What was needed was to make cuts in several directions and when the images were finally observed in the correct order the result would be a three-dimensional effect. Pirogov, therefore, made, in different cadavers, a series of transverse, longitudinal and anteroposterior cuts. A glass plate, on which was laid a sheet of paper on which rectangular grids were drawn, was placed over the cut. An accurate drawing was then made of the cut, allowing the detailed position and appearance of the various parts of the body to be recorded on marble in their natural position (Fig. 3).

To improve the separation of organs and structures such as plural folds, peritoneum, glands, heart valves, the cuts were first rinsed with warm water to remove frozen blood or serous fluids. The frozen layers were then allowed to thaw gradually, and pieces of ice carefully removed with an anatomical tweezer. In addition to the three-dimensional cuts they used another method, which Pirogov named the sculptural method, to display the very complex position of the abdominal organs. This involved using a chisel and hammer to carefully remove ice from areas frozen hard. After eight years work, Pirogov published his atlas of topographical anatomy in four volumes $[36-39,43]$. The fifth volume described and explained in detail the contents of plates in the first four volumes. The atlas had become a rarity by the beginning of the $20^{\text {th }}$ century but was reprinted in 1997 for a limited edition of 500 copies [22].

Pirogov did not claim originality in the use of his three-dimensional method; he was aware of the topographical atlases produced by earlier anatomists, based on the anatomy found at autopsies [55] However, Pirogov did claim that nobody before him had used a method similar to his, namely making thin cuts a frozen human corpse to achieve a three-dimensional image. Nor did he claim that his method was the only sufficiently accurate method to locate the exact position of the organs. On the contrary, he thought his method and the traditional methods should be used together for the most effective study of the position of organs. His method, however, was not only useful for topographical anatomy but also for histology and pathology. He, therefore, added drawings showing the position of organs whose location had been changed by disease.

The first drawings of the cuts using both methods, which he performed on frozen corpses in 1836 , were published in St. Petersburg in 1852 [36]. Two years later he submitted the first pages of the manuscript to the Parisian Academy of Sciences for their acknowledgement. This was the standard method to have a manuscript internationally accepted in the 19th century, the 


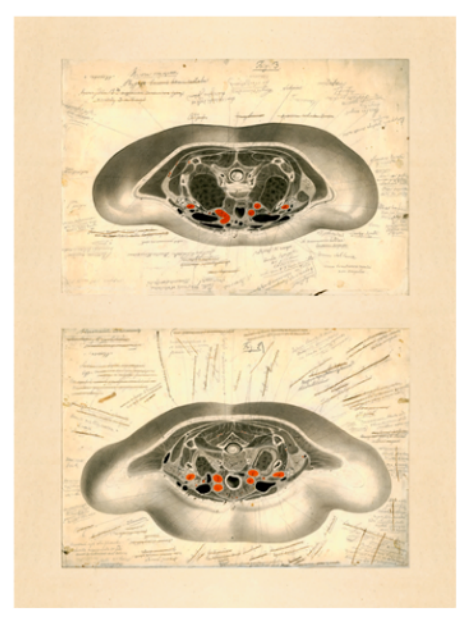

Plate I

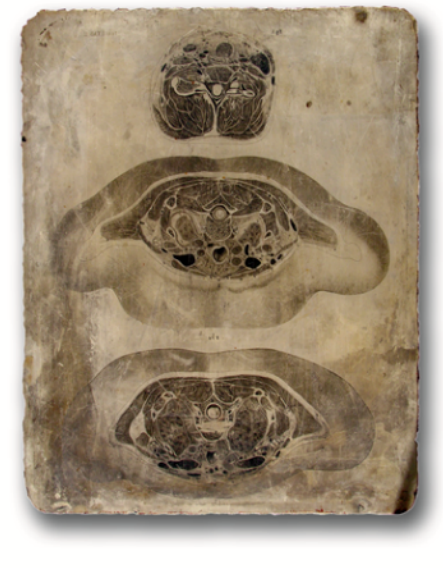

Plate II

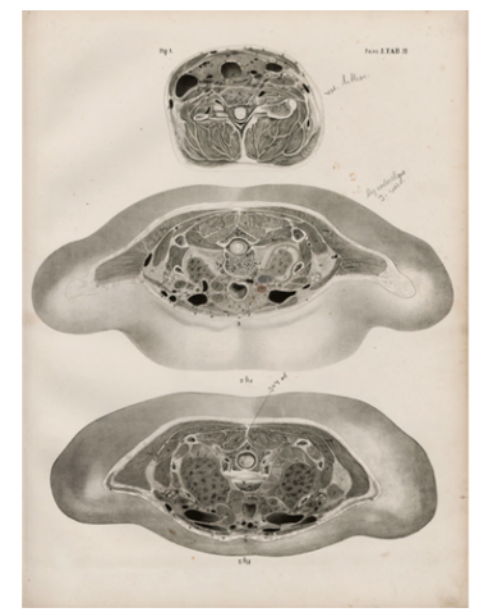

Plate III

Fig. 3. Plate I. The original drawings in their original seize and the handwritten explanation by Nikolay Pirogov, exhibited in the Nikolay I. Pirogov Museum in the Military Medical Museum in Saint Petersburg, Russian Federation. Reproduced with the permission from the Military Medical Museum of the Ministry of Defence of the Russian Federation, Saint Petersburg.

Plate II The marble stone on which the body cuts are engraved in their original size, exhibited in the Nikolay I. Pirogov Museum in the Military Medical Museum in Saint Petersburg, Russian Federation. Reproduced with the permission from the Military Medical Museum of the Ministry of Defence of the Russian Federation, Saint Petersburg.

Plate III The drawings as in plate I and II printed on page 18, Volume I of Pirogov's atlas of Topographic Anatomy [43]. In public domain.

equivalent to the peer-review process today [26]. Four years later, the Parisian Academy announced that a French doctor had made numerous coupes of frozen corpses and won a prize named after the Montyon Foundation [26].

Nikolay Pirogov received a letter dated $\mathrm{Au}-$ gust 10, 1862 about his three-dimensional topographic atlas from the renowned French surgeon Félix Hippolyte Larrey (1808-1895), in which he praised the quality of the atlas, and asked Pirogov's permission to discuss the atlas with his French medical colleagues [20]. In a second letter dated February 9, 1869 he informed Pirogov that after discussion with his colleagues they had decided to promote both the atlas and his textbook on military surgery [21] in France.

The topographical atlas was Pirogov's last work on medicine before he took part in the Crimean War from 1854-1856. After the Crimean War he resigned his position at the Imperial Medico-Surgical Academy and focused more on education and supervising students during their foreign internship in Germany. In 1897 during the XII International Congress of Medicine in Moscow, attended by approximately 10.000 physicians from all over the world, Pirogov was posthumously honoured with the following statement and also a monument of him erected in his honour: "...For a long time two main directions existed in surgery: empiricism and theory. For centuries the practice of our art was in the hands of artisans, who in the barbershop climbed from apprentice to companion. There was no more theory here than with other crafts .... Pirogov among his many other accomplishments had the great merit of contributing to the introduction of anatomy into surgery..." [5].

\section{Conflicting Interest}

No external funding or conflicting interests declared.

\section{Acknowledgments}

The authors are grateful for the immense and generous help and support they received from Mrs. Liudmila B. Narusova, President of the Anatoly Sobchak Foundation, for allowing access to the archives and libraries of museums and of scientific institutes in Saint Petersburg. We are also very thankful to Prof. Dr. A.A. Budko, director of the Military Medical Museum and his staff, and to Prof. Dr. A. Ya. Fisun, general director of the Military Medical Academy in Saint Petersburg and his staff for their kind support and enthusiasm.

\section{References}

1. Anon. On 11 February 1847 in the Second Military Land force Hospital was performed surgery without pain during the amputation of a female right breast while using of inhalation of sulferic ether vapour. Drug Zdraviya, Vrachebnaya Gazeta. 1847;15(8):57-64.

2. Anon. Boerhaave Herman (Hermannus). In Leiden Medical Professors 1575-1940. Leiden: Museum Boerhaave/LUMC Leids Universitair Medisch Centrum, 2007:85-8.

3. Avisov PB, Zhorov IS. Comments on the work of N.I. Pirogov. «Observations on the effect of ether 
vapour as analgesic in surgical operations». The problems of anaesthetization in his studies. In: Collected Works of N.I. Pirogov in Eight Volumes. Moscow: State Publisher Medical Literature, 1959:443-70.

4. Bigelow HJ. Insensibility during surgical operations produced by inhalation. The Boston Medical and Surgical Journal. 1846;35(16).309-17.

5. Braatz E. In: Roth W, ed.Minutes XII International Congress of Medicine. Moscow. 1897;5:320-36.

6. Brezhnev AP. Pirogov. Moscow: Molodaya Gvardiya; 1990.

7. Cessner CJ. Textboek for teaching about surigcal instruments and dressing. Vienna: Verlag von L.W. Seidel; 1852.

8. Defalque RJ, Wright AJ. The short, tragic life of Robert M. Glover. Anaesthesia. 2004 Apr;59(4):394-400. doi: 10.1111/j.13652044.2004.03671.x

9. Dinnick OP. Early textbooks on anaesthesia. Anaesthesia. 1988 Sep;43(9):807-8. doi: 10.1111/j.1365-2044.1988.tbo5785.x

10. Gaivoronskii $I V$. Historical essay on the department of normal anatomy of the military-medical (medical-surgical) Academy (On the $220^{\text {th }}$ anniversary of the foundation of the department). Saint Petersburg: SpetsLit; 2018.

11. Garibaldi G. A letter from G. Garibaldi with thanks for the treatment. Fundamental Library of the Military Medical Academy. 1863. III-38:5.

12. Hendriks IF, BovillJG, Boer F, Houwaart ES, Hogendoorn PCW. Nikolay Ivanovich Pirogov: a surgeon's contribution to military and civilian anaesthesia. Anaesthesia. 2014 Nov 4;70(2):219-27. doi: 10.1111/anae.12916

13. Hendriks IF, BovillJG, van Luït PA, Hogendoorn PC. Nikolay Ivanovich Pirogov (18101881): A pioneering Russian surgeon and medical scientist. Journal of Medical Biography. 2016 Mar 8;26(1):10-22. doi: 10.1177/0967772016633399

14. Hendriks IF, Bovil JG, Zhuravlev DA, Gaivoronsky IV, Boer F, Hogendoorn PCW. The role of Dutch representatives in the development of medicine in Russia from the 9th to the 13th century. Vestnik of Saint Petersburg University Medicine. 2019 Jun 25;14(1):49-57. doi: 10.21638/11701/spbu10.2019.106

15. Hendriks IF, Bovill JG, Zhuravlev DA, Gaivoronskii IV, Boer F, Hogendoorn PCW. The development of Russian Medicine in the Petrine era and the role of Dutch doctors in this process. Vestnik of Saint Petersburg University Medicine. 2019 Nov 14;14(2):158-72. doi: 10.21638/spbu11.2019.208

16. Hendriks I, Zhuravloyv D, Bovill J, Boer F, Hogendoorn $P$. Women in healthcare in Imperial Russia: The contribution of the surgeon Nikolay I Pirogov. Journal of Medical Biography. 2019 Jan 14:1-10. doi: 10.1177/0967772018818049

17. Hendriks IF, Zhuravlev DA, Bovill JG, Boer F, Gaivoronskii IV, Hogendoorn PCW, et al. Nikolay Ivanovich Pirogov (1810-1881): Anatomical research to develop surgery. Clinical Anatomy. 2019 Nov 11;33(5):714-30. doi: 10.1002/ca.23493

18. Kichigina G. The Imperial Laboratory. Experimental Physiology and Clinical Medicine in PostCrimean Russia. Amsterdam-New York: Editions Rodopi; 2009.

19. Langeveld $A R$. Oostenbroek RJ, Wijffels MP, Hoedt MT. The Pirogoff amputation for necrosis of the forefoot: a case report. J. Bone Joint Surg. Am. 2010;92(4):968-72.

20. Larrey FH. Letter to Nikolay I. Progov, 19 August 1862. Manuscript-letter. Fundamental Library of the Military Medical Academy named S.M. Kirov. Saint Petersburg, 1862;III-44:24.

21. Larrey FH. Letter to Nikolay I. Pirogov, 9 February 1869. Manuscript-letter. Fundamental Library of the Military Medical Academy named S.M. Kirov. Saint Petersburg, 1869;III-44: 25-26.

22. Lichterman $B$. Ice Anatomy by Nikolai Pirogov First published 1851-9. BMJ. 2008;336(7646):725.

23. Malis $Y G$. The establishment of the Department of Hospital Surgery at the St. Petersburg MedicalSurgical Academy. Vrach. 1896;3:63-9.

24. Messmer F. Karl Lang. The Scientific publications in their medical historical significance. Reflecting the history of surgery. Munich, Germany: Allitera Verlag der Buch\&media $\mathrm{GmbH} ; 2007$.

25. Metcalfe NH. The influence of the military on civilian uncertainty about modern anaesthesia between its origins in 1846 and the end of the Crimean War in 1856. Anaesthesia. 2005 Jun;6o(6):594-601. doi: 10.1111/j.13652044.2005.04183.x

26. Perpetuelles $S$. Compte de rendus hebdomadaires des seances de l'academie publies conformement a une decision de l'academie. Paris; 1857:175.

27. Pirogov NI. Annals of the Surgery Department of the Clinic at the Imperial University of Dorpat in 2 Volumes. Volume II. Dorpat, Imperial Russia: C.A. Kluge; 1839.

28. Pirogov NI. Full course of applied anatomy of the human body with drawings. Descriptivephysiological and surgical Anatomy. Saint Petersburg; 1844.

29. Pirogov NI. A full course of Applied anatomy of the human body. With drawings of Pirogov. Saint Petersburg; 1844.

30. Pirogov NI. New method for generating, by means of ether vapour, insensitivity in individuals subjected to surgical operations. Paper presented at the Comptes Rendus. Academie des Sciences. Quai des Augustis; 1847;55:789-91.

31. Pirogov NI. Practical and physiological research on etherization by N. Pirogoff. Saint-Petersburg: Fd Bellizard et Co., Libraires; 1847.

32. Pirogov NI. Medical Report of a Journey to the Caucasus, containing statistical comparison of amputations, experimental research of firearms injuries, and a detailed description of the anaesthesia results, obtained on the battlefield and in different hospitals in Russia. Saint Petersburg: Printing House of the Journal of Saint Petersburg; 1849.

33. Pirogov NI. Pathological Anatomy of the Asian Cholera. Atlas. Saint Petersburg: Karl Kray; 1849.

34. Pirogov NI. Anatomical images of the external appearance and position of organs in the three main cavities of the human body, designated primarily for forensic doctors. With full explanation. Saint Petersburg: The Military Medical Journal; 1850.

35. Pirogov NI. Pathological Anatomy of the Asian cholera. From observations of the epidemic prevailing in Russia in 1848. Saint Petersburg: Karl Kray; 1850.

36. Pirogov NI. An Illustrated Topographic Anatomy of Saw Cuts Made in Three Dimensions across the 
Frozen Human Body. Thoracic Cavity. Petropoli: Yakob Trey, 1852;2.

37. Pirogov NI. An Illustrated Topographic Anatomy of Saw Cuts Made in Three Dimensions across the Frozen Human Body. Petropoli: Yakobi Trey, $1853 ; 1$.

38. Pirogov NI. An Illustrated Topographic Anatomy of Saw Cuts Made in Three Dimensions across the Frozen Human Body. Abdominal and pelvic cavity. Petropoli: Yakob Trey, 1853;3.

39. Pirogov NI. An Illustrated Topographic Anatomy of Saw Cuts Made in Three Dimensions across the Frozen Human Body. Extrimitates. Petropoli: Yakob Trey, 1853;4.

40. Pirogov NI. Clinical Surgery. Osteoplastic extension of the lower leg bones in the disarticulation of the foot. Reflections on the difficulty of the surgical diagnosis and the good fortune in Surgery, illustrated by observations and case histories. Leipzig: Breitkopf und Hartel; 1854;1.

41. Pirogov NI. Clinical Surgery. The plaster adhesive bandage for simple and complex fractures and its application in transport and wounded on the battlefield. Leipzig: Breitkopf und Hartel; 1854.

42. Pirogov NI. Osteoplastic extension of the lower leg bones in the disarticulation of the foot. VoennoMedichintsinskiy Zhurnal. 1854;63(2):83-100.

43. Pirogov NI. An Illustrated Topographic Anatomy of Saw Cuts Made in Three Dimensions across the Frozen Human Body. In four volumes between 1852 and 1859. Saint Petersburg: Petropoli; 1859.

44. Pirogov NI. Broad guidelines for general war surgery, according to reminiscences from the wars in the Crimea and the Caucasus and from the hospital practice. Leipzig: Verlag von F.C.W. Vogel; 1864.

45. Pirogov NI. Collected Works in 8 Volumes. Volume I: Proceedings of Experimental and Clinical Surgery (1832-1840). Moscow: Gosudarstvennoe Izdatelstvo Meditsinskoy Literatury; 1957.

46. Pirogov NI. Collected Works in 8 Volumes. Volume III: Proceedings on experimental, operational and military surgery (1847-1854). MoscowLeningrad: Gosudarstvennoe Izdatelstvo Meditsinskoy Literatury; 1959.

47. Pirogov NI. Questions of Life. Diary of an Old Physician. Edited and with a new Introduction by Galina V. Zarechnak, Ph.D. Canton, USA: Science History Publications; 1990.
48. Pirogov NI. Researches Practical and Physiological on Etherization. English translation by B. Raymond Fink From the French original. Park Ridge, Illinois: Wood Library Museum of Anesthesiology; 1992.

49. Pirogov NI. Questions of Life. Diary of an old physician, written exclusively for himself, but not without a second thought, that may be somewhere somebody will read it also. 5 November $1879-22$ October 1881. Reprinted by the publisher. NorthWest, Russia: Knigovek Knizhny Klub; 2011.

50. Ring A. Nikolaj Pirogov: a pioneer of modern surgery. Chirurg 2011;82(2): 164-8.

51. Ruychaver MJ. Treatise of the immovable dressing modified by Dr. Seutin. Rotterdam. The Netherlands: C. Blommendaal; 1839.

52. Secher $O$. Early textbooks on anaesthesia. Anaesthesia. 1987 Sep;42(9):1022. doi: 10.1111/j.13652044.1987.tbo5394.x

53. Shabinin AV, Zhuravlev DA. The year 1847 in the life and works of N.I. Pirogov. Vestnik Istorii Voennoy Meditsiny. 2004:128-34.

54. Shalaev $S A$. N.I. Pirogov - founder of the first hospital surgical clinic. Grekov's Bulletin of Surgery. 1991;146:130-2.

55. Standring $S$. A brief history of topographical anatomy. Journal of Anatomy. 2016 Jun 9;229(1):3262. doi: 10.1111/joa.12473

56. Taniguchi A, Tanaka Y, Kadono K, Inada Y, Takakura Y. Pirogoff Ankle Disarticulation as an Option for Ankle Disarticulation. Clinical Orthopaedics and Related Research. 2003 Sep;414:322-8. doi: 10.1097/01.blo.0000079444.64912.d6

57. Vasiliev C. Pirogov. Leningrad: Lenfilm; 1947.

58. Virchow R. Pathological anatomy of CholeraMorbus. Carl Christian Schmidt's Jahrbücher der in- und ausländischen gesammten Medicin. 1852;73:359-77.

59. Nikolai Pirogov - a surgeon from God [accessed 17/09/2014].

60. Zhorov IS. Development of surgical anaesthesia in Russia and the USSR: Minutes of experience by NI Pirogov December 21, 1847 at the University of Moscow to study the direct action of chloroform on the nervous system with the assistance of dissector Alexey N. Orlovsky. Moscow: Academy Medical Science; 1951.

Для цитирования: Hendriks I.F., Zhuravlev D.A., Bovill J.G., Boer F., Hogendoorn P.C.W., DeRiuter M.C., Gaivoronskii I.V. Николай Иванович Пирогов как инноватор в анатомии, хирургии и анестезиологии. Часть II. Журнал анатомии и гистопатологии. 2020; 9(3): 102-110. doi: 10.18499/2225-7357-2020-9-3-102-110

For citation: Hendriks I.F., Zhuravlev D.A., Bovill J.G., Boer F., Hogendoorn P.C.W., DeRiuter M.C., Gaivoronskii I.V. Nikolay Ivanovich Pirogov as an innovator in anatomy, surgery, and anaesthesiology. Part II. Journal of Anatomy and Histopathology. 2020; 9(3): 102-110. doi: 10.18499/2225-7357-2020-9-3-102-110 